\title{
MAKING LARG SUPPLY CHAIN MANAGEMENT SMART AND IDENTIFICATION OF ITS CONDITIONS WITH MANAGEMENT TOOLS OF SWOT, BI, AND RFID TECHNOLOGY
}

\author{
Ali Ramezani Ghotbabadi ${ }^{1}$, \\ ShahrbanooTajmiri Gandaee* ${ }^{2}$, \\ Mohammad Tajmiri Gandaee
}

\begin{abstract}
In the information age and complex competitive environment in the world of global competition, the senior managers of organizations and companies require timely and correct decisions in order to maintain the demand-oriented in order to maintain market demand-oriented and customer retention and retain customer. Thus, for any decision-making and planning in organizations and companies, we should identify the current situation through investigation of internal and external environmental factors known so that we predict future. The present study aimed to make LARG supply chain management smart and to identify its conditions with management tools of SWOT, BI and RFID technology. This study is applied and its method is descriptiveanalytic. Results of studies show that the management of programs and organizational activities are not limited to within the organizations. Therefore, organizations and companies, including manufacturing, services companies, can provide managements goals of LARG supply chain in all manufacturing and service chains that has advantages of lean, agile, resilient, and green approaches to achieve success by identifying internal and external environmental factors using analyzing tool of SWOT along with business intelligence and radio Frequency Identification technology (RFID).
\end{abstract}

Keywords: supply chain management, LARG supply chain management, management tools of SWOT, business intelligence (BI), radio Frequency Identification technology (RFID)

\section{Introduction}

In today's highly competitive environment, the key to sustainable competitive advantage is activity within the supply chain and providing high quality services [4]. Globalization of business and information technology development have caused that supply-oriented market changes to demand-oriented market and organizations meet their customers' needs to survive in the competitive business. Accordingly, the base of supply chain management became important [27].To protect their competitive advantage against competitors, companies are continually meeting their customer needs. One of the key characteristics of competitive business in the world today is to pay attention to competitive issues of supply chain [19]. To identify opportunities and threats, environmental analysts investigate the effects of environmental variables on all sectors and bodies of organizations, including the inputs and outputs. In other words, through environmental analysis, opportunities and threats are identified and internal weaknesses and strengths of the organization are identified, goals are determined, and procedures and organizational policies are specified. Management tool assists management to adopt an integrated approach [1].Today, more organizations have realized that information is the lifeblood of e digital economy and the key to success in era of information is to make clear, better and faster decisions in the competitive field. Inappropriate business decisions, decisions based on incomplete information, can bring many losses [23].According to the Government Accounting Office (GAO) of America RFID is a technology that is used to identify, track and store the information electronically. In simple terms, this technology is a system that uses radio frequencies read by a receiver to transmit the identity of an object or person in the form of wireless [20].One of the most important

\footnotetext{
${ }^{1}$. Ph.D. (Marketing), Faculty of management, nonprofit institute of Zand Higher Education, Shiraz, Iran. Email: rgali1981@gmail.com

2 . MA. Student, Industrial engineering, nonprofit institute of Zand Higher Education, Shiraz, Iran.

3 . MA. Student, Business administration, Islamic Azad University Malayer Branch, Iran
} 
decisions in the supply chain is the efficiency and effectiveness of this chain along with parameters and variables having uncertainty [5]. Initiatives to improve supply chain performance are trying to match supply to demand and thus reduce costs while improving customer satisfaction. This requires that the uncertainty in the supply chain is reduced to the maximum so that facilitates the more predictable demand above the chain [37].To predict and optimize the process of right selection in each supply chain activities, including selection of suppliers, the manufacturing sector (entry of raw goods, process manufacturing, assembly, etc.), managers of supply chain need to make proper decisions with minimal measurement error. To measure different conditions such as reliability and non-reliability, we can use SWOT analysis tool. The flow of information is provided by key components of supply chain. The presence of correct and information quickly accessible is one of the basic needs of the management, and all employees in the lower sectors. Therefore, by knowing the conditions and use of intelligence technology business that converts raw data into knowledge and auto detection of information and recording them, we can create synchronized management among employees in different sections of LARG supply chain. In addition, by doing this we can achieve its goals such as reducing costs (due to the correct information of the product, product design, product manufacturing process, transportation of goods, personnel, etc.), increased profitability (due to reduced costs, managing recycling products), the establishment of partnership relations (due to a full understanding of the situation by means of SWOT and business intelligence technology and RFID).

\section{Importance of study}

In recent years, with increasing levels of competition in the global market, numerous studies have been done on the use of information technology as a way to improve production processes in supply chain management [33]. Supply chain consists of two or more organizations that are legally separated and they are linked by materials, information, and financial flows. These organizations can be companies that produce parts, components and finished products, and even they include providers of logistic services for final customer. The aim of all those who work in the supply chain is increasing the competitiveness [15].Competitiveness, reduces costs, survive in market, customer retention, increased profitability, protect the environment, and keep pace with the increasing globalization of markets and customer expectations, have led to new approaches to supply chain management. LARG supply chain management is based on four approaches of lean, agile, resilient and green approaches that its management needs rapid and comprehensive information on the selection and decision-making to achieve the goals. By identifying optimal conditions and opportunities by means of SWOT and pervasive use of business intelligence technologies that are efficient converters of information into knowledge along with technology to detect radio frequencies that receive, record, maintain, and transmit information, the power of monitoring and controlling information-based activities supply chain will be possible.

\section{Methodology}

Research is divided into three categories based on goal, including basic research, applied research and developmental research [17]. The present study is descriptive and analytical in terms of nature and method. In descriptive and analytical studies, researcher not only states the problem but also he explains and describes the problem and its dimensions [9]. This study is applied in terms of type and goal that aims to achieve a logical framework to explain the LARG supply chain management by SWOT, BI, and RFID technology. 


\section{Theoretical review of literature}

\section{LARG supply chain management}

Supply chain environment is more dynamic and unpredictable than in the past. Therefore, it must be reconfigured to respond the changes [38]. Supply chain management has become a tactical asset for the current state of global competition. Innovative strategies such as lean, agile, resilient and green emerged, as an emerged response, need for high levels of collaboration and great complexity. However, the consistency of strategic operations with supply chain partners has collaboration capacity [39].Using four approaches of LARG supply chain, lean approach in a supply chain by reducing the cost, agility approach to maximize profits by providing accurate customer requirements, resilient approach may not have the lowest cost but it has higher capacity to confront with uncertain business environment. In addition, environmental policies should also ensure that the system is stable. Exchanges between the lean, agile, resilient and green approaches are real management issues, and may help supply chain to become more effective and more sustainable [31].They include features, organizational systems, informational systems, human factors, performance measurement technologies[39]. In order to investigate the establishment of approaches in supply chain management, creation of relationship between the supply chain features (derived from the establishment approaches) was necessary by selecting key performance indicators. Figure 1 shows the cause and effect relationships between supply chain performance indicators and features.

\section{Fig 1: Performance indicator supply chain attributes relationships.}

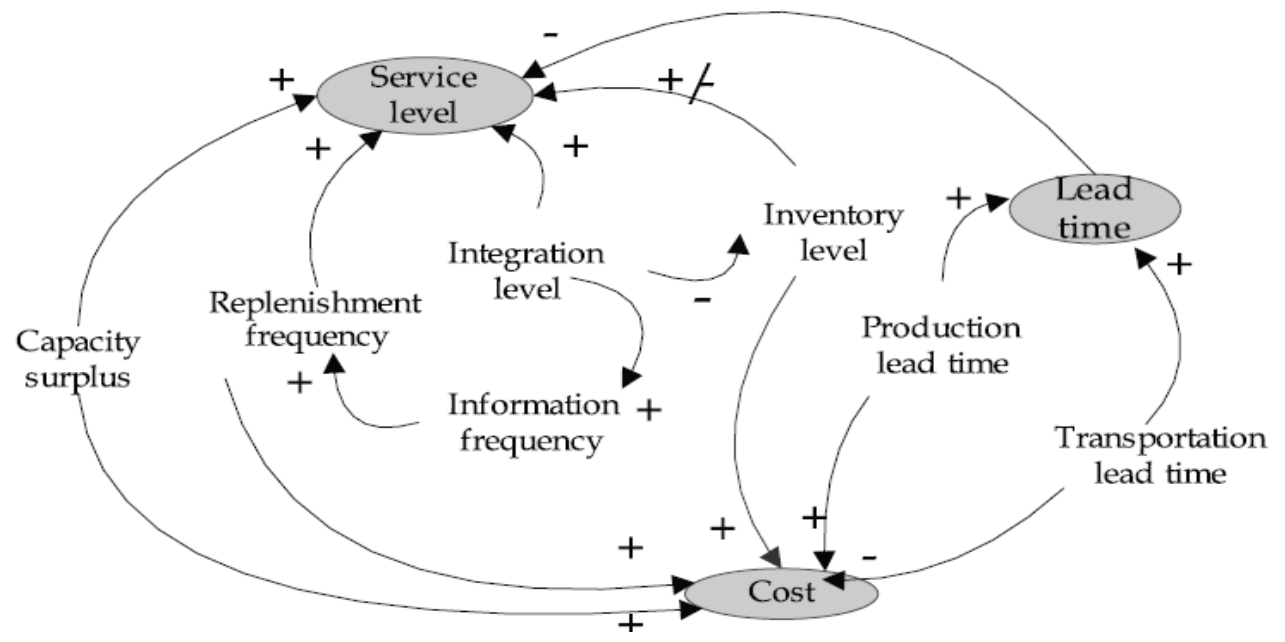

(Source: [40])

Cause and effect figure was selected to show the dynamics of the supply chain. By using this figure, it will be possible to imagine the impact of supply chain features on indicators. The positive links mean that two nodes move in the same direction [40].

\section{Lean Supply Chain Management}

Lean manufacturing is a term introduced by John Krafcik, (responsible to develop Hyundai in America) and International Motor Vehicle Program (IMPV) researcher. This mode of manufacturing reduces the manpower in the factory, space needed for manufacturing, capital spent on equipment, engineering force and time needed for the creation of new products by half. In addition, in the lean manufacturing, needed stock out-cost reduces over than $50 \%$ and products are supplied with high variety [43]. This approach is based on reducing the cost and flexibility, focusing on process improvement by reducing or eliminating all the "waste" or non-value added of operations [42]. 


\section{Agile Supply Chain Management}

To survive in dynamic and changing markets, supply chain requires a tool that can overcome environmental challenges by its help. Such tool is agility [7]. Agility in the supply chain is defined as the ability of a supply chain to respond quickly to changes in the market and customer needs. Agile supply chain can be considered as structure aims to satisfy the needs of customers and employees in which each organization can develop its business strategies, processes, structure and informational systems [18].

\section{Green Supply Chain Management}

Green supply chain involves phases of the product life cycle from design to recycling. Adopting investment strategies in improving the environmental performance of the supply chain includes many advantages and benefits such as saving energy, reduced pollutants, faster delivery of goods and services, reduce latency, lower costs and increased quality. In addition, it will result in competitive advantage by creating added value for customers due to supply of green products [3].

\section{Resilient Supply Chain Management}

One way of dealing with changes in production and market conditions is the concept of supply chain and its increased flexibility to meet the different needs of customers [8]. Supply chain flexibility is the ability of different systems to meet various customer expectations in less time, cost, functional loss and organizational disorders [30].

\section{SWOT Analyst management tool}

1. SWOT is acronym of strengths, weaknesses, opportunities and threats [1]. Rules governing analytical matrix of this tool include:

Aggressive strategies: maximum strategies to use environmental opportunities using the strengths of the organization

2. Conservative strategies: strategies to take potential advantages lean environmental opportunities to compensate for weaknesses in organization

3. Competitive strategies: strategies to use organization's strengths to avoid exposure to threats

4. Defensive strategies: strategies to minimize losses caused by threats and weaknesses [2].

\section{Business Intelligence}

Large amounts of data exist in information systems of organizations. Part of the data is obtained by domestic transactions and part of them is obtained by external sources. However, even if they are collected and stored in systematic and structured models, they cannot be directly used for decision-making. These data should be extracted by appropriate tools and processed by analytical methods so that they can be converted to knowledge in order to use them management decision-making process. The most important benefit of using business intelligence systems is to enhance the effectiveness of the decision-making process [22].

\section{Radio frequency identification technology}

This technology has a wide and rapid growth in industry and services. RFID technology provides an innovative and automated system for intelligent management [16]. The system includes the following components:

1. Tag Transmitter

2. Data Reader and antennas

3. Software

In general, Radio frequency identification technology is wireless identification system that is able to exchange data between a tag connected to an object and data reader. Tag is device connected to the product that we want to detect or track it. Tag is a combination of chip and antenna. Chip has been embedded by antenna and sends the information necessary to identify the considered item for a reader. The reader converts the radio frequencies returned from the RFID tag to digital information. Then, it provides the possibility of sending data for computer to its processing [20]. 


\section{Integration goals Lean, Agile, Green and Resilient approaches}

The aim of integration of the four approaches in the form of LARG supply chain management is to find common grounds on five common visions of integration, including integration of customer, internal integration, provider of materials and services integration, technology integration and planning, and communication integration [21]. Big data, advanced analysis, and record patented in-memory database are the agenda of senior management because they are empowering keys in increasing the business decisions [29].The first step in a strategic planning process is to determine the missions and goals of the organization. Then, by using SWOT analysis as one of the tools to develop strategy, we can develop strategy that is appropriate to the environment. By using this analysis, first, we can begin to analyze the internal and external environments of organizations [1].Second, by understanding the environment and the supply chain in the manufacturing and service organizations, use of BI technology that includes a set of wide range of applications, such as Report Builder, an online analytical processing [6] and RFID technology that enables the system to record the data in tags and transmit them to a computer [20].we can make optimized decisions with the utmost reliability.

\section{Review of literature}

The word LARG was created by placing Latin first letters of four approaches of supply chain together. The idea of LARG supply chain management was shaped in the Mechanical Engineering \& Industry Research Unit, Faculty of Science and Technology, Universidade Nova de Lisboa. Currently, this research unit is known as the main reference in this regard [28]. The project proceeded until March 2013, and the majority of articles on LARG published in this period were published by this team. Industrially, this project was case studied in the Volkswagen factory in Autoeuropia that part of it has been implemented.over time, due to problems created in supply chain field for different companies, this idea was primarily focused by many researchers that this domain has been reached within the borders of Iran [44].

Examples of research on supply chain management approaches and their relationship with technologies are shown in Table 1.

\section{Table 1: Review of literature}

\begin{tabular}{|c|c|c|c|c|}
\hline researchers & \multicolumn{2}{|l|}{ Title study } & \multicolumn{2}{|c|}{ Main goal of study } \\
\hline $\begin{array}{l}\text { Doroudchi and } \\
\text { Nikmehr (2007) }\end{array}$ & $\begin{array}{l}\text { Studying the importance of } \\
\text { information technology in sup } \\
\text { chain management }\end{array}$ & & $\begin{array}{l}\text { Investigation of the impacts } \\
\text { supply chain management at } \\
\text { affecting the adoption of inform }\end{array}$ & $\begin{array}{l}\text { IT applications on } \\
\text { providing factors } \\
\text { tion technology }\end{array}$ \\
\hline \multicolumn{2}{|c|}{$\begin{array}{l}\text { How customers identify and understand the logistics } \\
\text { service providers in terms of achieving the desired } \\
\text { benefits in allocation of resources? }\end{array}$} & \multicolumn{2}{|c|}{$\begin{array}{l}\text { Investigation of the concepts and } \\
\text { functions of PLs (third party logistics } \\
\text { provider) in the supply chain }\end{array}$} & $\begin{array}{c}\text { Hayat } \\
\text { davoodi }(2007)\end{array}$ \\
\hline \multicolumn{2}{|c|}{$\begin{array}{l}\text { Combined approach assessment of ANP and } \\
\text { evaluation laboratory and decision test to evaluate } \\
\text { comparisons of lean, agile and lean -agile supply } \\
\text { chain strategies in Dizel Sang Company of Iran }\end{array}$} & \multicolumn{2}{|c|}{$\begin{array}{l}\text { Evaluation of comparison of lean, } \\
\text { agile and lean -agile supply chain } \\
\text { strategies }\end{array}$} & $\begin{array}{l}\text { Gadiklaeeet } \\
\operatorname{al}(2011)\end{array}$ \\
\hline \multicolumn{2}{|c|}{$\begin{array}{l}\text { Holding communication between RFID technology } \\
\text { and information systems in decision-making in the } \\
\text { supply chain }\end{array}$} & \multicolumn{2}{|c|}{$\begin{array}{c}\text { The use of RFID and informational } \\
\text { systems in NAJA supply chain } \\
\text { management }\end{array}$} & $\begin{array}{c}\text { Rastegar and } \\
\text { Baratimosleh(2014) }\end{array}$ \\
\hline \multicolumn{2}{|c|}{$\begin{array}{l}\text { Simulation of the supply chain (for flexibility) in } \\
\text { relation to the automobile supply chain in Portugal }\end{array}$} & \multicolumn{2}{|c|}{$\begin{array}{l}\text { Supply chain redesign for resilience } \\
\text { using simulation }\end{array}$} & $\begin{array}{l}\text { Carvalho et al } \\
\text { (2012) }\end{array}$ \\
\hline \multicolumn{2}{|c|}{$\begin{array}{l}\text { Providing a GIS-BIM model in determination of } \\
\text { flow of materials, availability of resources, and } \\
\text { "map" of visual supply chain }\end{array}$} & \multicolumn{2}{|c|}{$\begin{array}{l}\text { Integrating BIM and GIS to improve } \\
\text { the visual monitoring of construction } \\
\text { supply chain management }\end{array}$} & Irizarry et al (2013) \\
\hline
\end{tabular}




\begin{tabular}{|l|c|c|}
\hline $\begin{array}{l}\text { Providing an integrated evaluation model based on } \\
\text { green and resilient approaches for evaluating } \\
\text { automobile supply chain and using the Delphi } \\
\text { method to get the weight of the supply chain } \\
\text { approaches }\end{array}$ & $\begin{array}{c}\text { Ecosilient Index to assess the } \\
\text { greenness and resilience of the } \\
\text { upstream automotive supply chain }\end{array}$ & $\begin{array}{c}\text { Azevedo et al } \\
(2013)\end{array}$ \\
\hline $\begin{array}{l}\text { evaluating the conditions and the link between lean } \\
\text { management, supply chain management and } \\
\text { sustainable development, according to two points }\end{array}$ & $\begin{array}{c}\text { Lean Management, Supply Chain } \\
\text { Management and Sustainability: A } \\
\text { Literature Review }\end{array}$ & $\begin{array}{c}\text { Martínez-Jurado } \\
\text { and Moyano- } \\
\text { Fuentes } \\
\text { (2014) }\end{array}$ \\
\hline $\begin{array}{l}\text { Describing the development and evaluation of a } \\
\text { resilient decision support tool that evaluates the } \\
\text { effect of ES in supply chain management and } \\
\text { bridging the gap in evaluation tool of portfolio in } \\
\text { supply chain management }\end{array}$ & $\begin{array}{c}\text { Building and evaluating ESET: A tool } \\
\text { for assessing the support given by an } \\
\text { enterprise system to supply chain } \\
\text { management }\end{array}$ & $\begin{array}{c}\text { Peiris at al (2015) } \\
\text { Panini Amitha }\end{array}$ \\
\hline $\begin{array}{l}\text { Tests stock out-cost management system of vendor } \\
\text { by sharing stock out-cost sharing between suppliers } \\
\text { and customers using EOQ model }\end{array}$ & $\begin{array}{c}\text { Supply chain coordination in vendor- } \\
\text { managed inventory systems with } \\
\text { stockout-cost sharing under limited } \\
\text { storage capacity }\end{array}$ & $\begin{array}{c}\text { Jun-Yeon Lee et al } \\
\text { (2016) }\end{array}$ \\
\hline
\end{tabular}

\section{Results}

The disadvantage of lack of proper management in the supply chain is bullwhip effect. It states that although customer's demand for certain products does not change so much, stock out-cost levels and backlog orders considerably fluctuate across the supply chain. Increase of these fluctuations is moving up the supply chain (the first supplier). One of the methods to confront with this effect is reducing the uncertainty, reduced variability, reduced delivery time and the harmonization of the use of information and communication technologies, process integration and advanced planning [24].Increasing reliability supply chain is possible by identifying domestic and foreigner conditions by SWOT analysis tool. Increased and extended service and selections with minimal error, using BI technology that is very efficient tool in the decision-making along are associated with the use of radio frequency identification technology to receive, record and maintain information, particularly in the production chain (operational section) to identify and record of input materials, semi-products, products, products in stock, delivered products, and recycled products. Conceptual model of study is shown in Figure 2.

Fig 2: Conceptual model of study

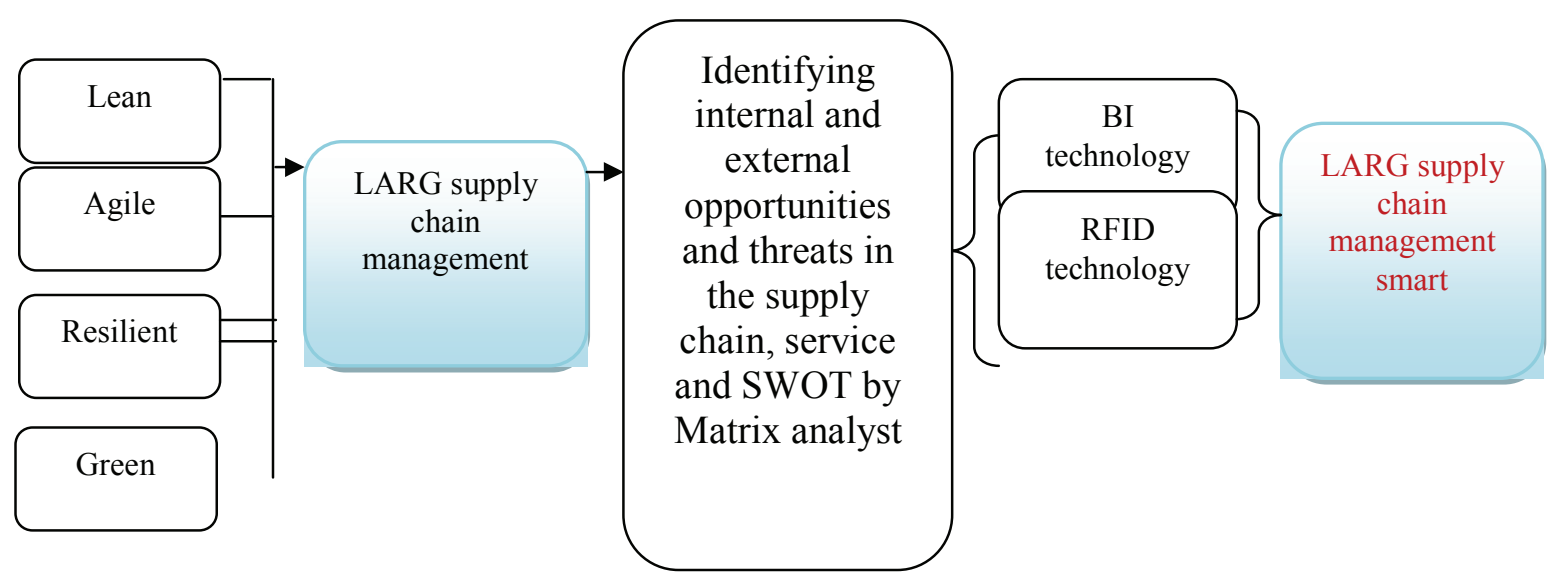

RFID technology has the ability to identify elements in a supply chain, as an important factor in applying management controls is desirable times and places. Providing annual reports, repairs and maintenance, avoiding from materials shortages and using security 
policies are only part of the capabilities of this technology [13].Continuous awareness of place and the movement of goods, equipment and devices and also awareness of the working status of the system according to charts and reports that smart system of operations provides for managers based on systemic analyses, results of analysis on these data, databases, and data stores in supply chain using radio ID with these systems to update data in the database provide extra in chain information systems [26]. To make appropriate decisions with minimum error by chain managers throughout the chain, internal and external environment conditions must be determined. Supply chain management is the cornerstone of the success of Wal-Mart and is considered as the main competitive advantage in warehouse retail industry. Their distribution system is considered as the most efficient system. Their emphasis in supply chain management is sharing information with suppliers. The focus will be on newly approved strategy and construction of green logistic processes. The manager of company is committed to three ambitious goals in supply chain management, including supply of 100 percent by renewable energies, to create zero wastes and to sell products to conserve resources of Wal-Mart and environment [25].Wal-Mart chain management strategy that was recognized as the largest company in the world in 2013, based on revenue, by means of SWOT analysis is shown in Table 2.This chain store includes company of household products, food, and supermarket and hypermarket. Domain of activity of this company is retailing. Wal-Mart's business is conducted in five sections of stores, Supercenters, local markets, Sam clubs, and international stores [10].

Table 2: SWOT strategy in wal-mart store analysis

\begin{tabular}{|l|l|}
\hline Respected and powerful brand, Reasonable pricing, Loyal & strengths \\
Customers, Powerful Strategy, Extensive range Product, & \\
\hline $\begin{array}{l}\text { So weakness in the coverage Extensive area of his range despite } \\
\text { using technology, Health and safety risks of some goods, Less } \\
\text { flexibility ina variety of products than its competitors }\end{array}$ & weaknesses \\
\hline $\begin{array}{l}\text { Focusing on specific markets such as China, Using of new locations, opportunities } \\
\text { expand market }\end{array}$ & threats \\
\hline $\begin{array}{l}\text { Big competitors, intense price competition, The new regulations, } \\
\text { tariffs taxes }\end{array}$ & the \\
\hline
\end{tabular}

Organizations can use SWOT analysis tool as the core of the organization's strategic plan to find the path or direction of the market [10].

\section{Conclusions and Recommendations}

As mentioned, big data, advanced analyses, and recording in-memory database technology are the agenda of senior management because they are empowerment keys to enhance business decisions. Certainty and uncertainty conditions can be estimated by analyzing the current situation. Evaluation of current conditions, forecasting the future conditions and use of IT systems such as BI and RFID resolve the LARG supply chain problems and make it smart. It is recommended that researchers assess and evaluate LARG supply chain management in manufacturing and service sectors such as the automobile, tourism, etc in their field studies.

\section{References}

[1]. Amani, A, R. (2010). Approach to Analytical Methods SWOT. Master thesis of business management.

[2]. Amini, M, T., \& Khebaz Bavil, S. (2009). Strategy Codification approach a comprehensive framework strategy: Case Study: Automotive Tabriz Sahand Company. Journal of Business management, Volume1, Issue2. 
[3]. Emani, D, M., \&Ahmadi, A. (2009). Green supply chain management, new strategies to gain competitive advantage. Journal Automotive engineering and related industries, Volume 1, Issue 10.

[4]. Azar,A.,\& Mohammad lo,M A. (2010). Designservices qualityin the supply chain model: Explainingthe concept of qualityinteractive services. Quarterlyprospectbusiness management. Issue 1.

[5]. Azar., A \&Mousavi, S, F. (2014). Stochastic model design basedand integratedthree-stepapproachfor the selection ofsupplierswithuncertainty.InOperations ResearchApplications, Volume 11, Issue 1.

[6]. TajmiriGandaee, Sh., Tavallaee, R.,TajmiriGandaee.,M. (2015). Assessment ofthe prospect for business intelligence(BI)insuccessfulbrandmanagementin organizations, International conference on management economics and industrial engineering, Tehran.

[7].Tizro,A., Azar,A.,Ahmadi,R.,Rafiee,M. (2011). Offer SupplyChainModel Case Study:Steel ZobAhan Company. Journal ofIndustrial Management. Volume 3, Issue 7.

[8]. JaafarNejad,A.,\&Yasaee, M. (2014). Mathematicalmodeling ofsupply chain flexibilityusinggoal programming. Journal-Industrial ManagementStudies, Volume 12, Issue 33.

[9]. Hafez niya, M. R. (2007). Introduction toResearch MethodsinHuman Sciences. Tehran, Publishers Semat.

[10]. Hdadi, A. (2014). Comparativestrategic managementchain store Refah with chain store Wal-MartConvenience. Project.

[11]. Hayat Davoodi, S. (2007). Investigation of the concepts and functions of PLs (third party logistics provider) in the supply. The firstinternational conference onsupply chain managementandinformation systems.

[12]. Doroud chi, M.,\&NikMehr, N. (2007). Studying the importance of information technology in supply chain management. Fourth National Conference onElectronic Commerce

[13]. Rastegar, A.,\&BaratiMosleh, M. S. (2014). The use of RFID and informational systems in NAJA supply chain management .Journalscientific-promotional ideaAmad, Volume 13, Issue 48.

[14]. Rouhani, S., Ghazanfari, Ma., Jaafari,M., TaqaviFard, M. T,. (2008). ERPbusiness intelligenceneedsassessmentCase StudyTrade Promotion Organization ofIran. .Journalnewbusinesseconomy. Issue 13.

[15]. ZangiraniFarahani, R.,\&Asgari, N. (2006). Supply Chain Management (EditingHartmutEsslinger\&Christoph Kilger,2005). Tehran, AmirkabirUniversity Publishers.

[16]. SalimiFard,KH.k., Khosravi,A.R., Pak,O.,Paseban,S.,Safaee,Z,. (2014). Modelingthe factors affectingreception RFID technology In the library(sample: BushehrUniversity of Medical SciencesLibrary. Researchlibraries andacademic information. Volume 1, Issue 48.

[17]. Sarmad,Z.,Bazargan, A., Hejazi, E. (1999). Research methodsin the behavioral sciences, Tehran, PublishersAgah, second edition.

[18]. Shahaee, B. (2006). Componentsandfeatures of theagile supply chain. First National Conference onIndustrial Management.

[19]. SafaeeGhadiklaee, A. H.,Akbarzade,Z,. Ahmadi,A. (2011). Assessment ofcomparative supply chainstrategies,lean, agileandlean-agile. Journalofexecutive management. Volume 3, Issue 6.

[20]. Sanaiee, A., Ghazi Fard, A.M., Sobhanmanesh, F. (2011). Factors affecting thedevelopmentofradio frequencyidentificationtechnology(RFID)in theelectronic supply chain management(E-SCM): Case Study: Iran Khodro Company, Journal ofMarketingResearch,Modern. Volume 1, Issue 1. 
[21]. Ghazi zade, M., Norouzzade, F., RaeesiGhorbanAbadi., H. (2015). AnalysisLARGe Supply chainmanagement usingDemateltechnique inSaipa Company. JournalSupply chainmanagement. Volume 17, Issue 48.

[22]. Lajevardi, S.J., \&Rahimi Pour, A. (2012). Business intelligenceandits impact on theimprovement ofportmanagement. JournalPerspective.

[23]. Mohaghar,A., Lox, K., Hossieni, F., Ali Monshi,A. (2008). Useing of Business Intelligenceasa Strategic Information Technologyin Banking:fraud discovery and detection. JournalInformation Technology Management. Volume 1, Issue 1.

[24]. Marangi, F., Abedi,M., Haghjo,N., Hashemi,S.F. (2014). LeanSupply Chain Management. Project.

[25]. Heying, A,. \& Sanzero,W .(2009) .A Case Study of Wal-Mart's Green Supply Chain Management.

[26]. Bhargava, H., \& D. J. Power .(2007) .Decision Support Systems and Web Technologies: A Status Report .Proceedings of the 2007 Americas Conference on Information Systems, Boston.

[27]. Boks, C,. \&Stevels, A .(2007) .Essential Perspectives for Design for Environment. Experiences from The Electronics Industry .International Journal of Production Research 45 , $.4039-4021,(19-18)$

[28]. Carvalho, H., \& ,.Machado, V. C. V. C .(2009) .Lean, agile, resilient and green supply chain: a review. Third International Conference on Management Science and Engineering Management), pp. 3-14). Bangkok, Thailand.

[29]. G.J. Hahn, J. Packowski (2015) .A perspective on applications of in-memory analytics in supply chain management .Decision Support Systems, Volume 76, Pages 45-52.

[30]. Grigore, S.D .(2007) .Supply Chain Flexibility .Romanian Economic and Business Review.70-66,(1)2,

[31]. Carvalho,H., \& V. Cruz-Machado .(2011) .Integrating Lean, Agile, Resilience and Green Paradigms in Supply Chain Management (LARG_SCM .(UNIDEMI, Department of Mechanical and Industrial Engineering Faculdade de Ciências e Tecnologia da Universidade Nova de Lisboa Campus Universitário, 2829-516 Caparica „Portugal.

[32]. Carvalho, H.,Ana P. Barroso,. Machado, V.H., Azevedo, S., V. Cruz-Machado . .(2012)Supply chain redesign for resilience using simulation .Computers\&Industrial Engineering, Volume 62, Issue 1, Pages 329-341.

[33]. Irizarry, J., Karan, E.P., Jalaei,F .(2013) .Integrating BIM and GIS to improve the visual monitoring of construction supply chain management .Automation in Construction , Volume 31 ,Pages 241-254.

[34]. Jun-Yeon Lee, Richard K. Cho, Seung-Kuk Paik .(2016) .Supply chain coordination in vendor-managed inventory systems with stockout-cost sharing under limited storage capacity .European Journal of Operational Research, Volume 248, Issue 1, 1 January 2016, Pages 95-106.

[35]. K. Dharini Amitha Peiris, Jin Jung, R. Brent Gallupe .(2015) .Building and evaluating ESET: A tool for assessing the support given by an enterprise system to supply chain management .Decision Support Systems, Volume 77, Pages 41-54.

[36]. BIBLIOGRAPHY $\backslash 11033$ Martínez-Jurado,P. J.,\& Moyano-Fuentes,J. (2014). Lean Management, Supply Chain Management and Sustainability: A Literature Review. Journal of Cleaner Production, Volume 85, PP 134-150.

[37]. Mason-Jones, R., Naylor, B., and Towill D.R., (1999). Lean, Agile, or LeagileMatching Your Supply chain to the Marketplace. Proc. 15th Int. Conf. Prod. Res., Limerick, PP 593-596.

[38]. Abdollahi, M., Arvan,M., Razmi,J .(2015) .An integrated approach for supplier portfolio selection: Lean or agile ?Expert Systems with Applications ,Volume 42, Issue 1, Pages 679-690. 
[39]. BIBLIOGRAPHY 11065 Botelho, P. E. (Espadinha da Cruz, Licenciado em Engenharia Química e Biológica - Ramo Química .(2012) .(Lean, Agile, Resilient and Green Supply Chain Management Interoperability Assessment Methodology .Dissertação para obtenção de grau de Mestre em Engenharia e Gestão Industrial (MEGI).

[40]. Sterman, J .(2000) .Business Dynamics: Systems Thinking and Modeling for a Complex World .New York: McGraw-Hill.

[41].Susana G. Azevedo, Kannan Govindan, Helena Carvalho, V. Cruz-Machado . .(2013)Ecosilient Index to assess the greenness and resilience of the upstream automotive supply chain .Journal of Cleaner Production, Volume 56, Pages 131-146.

[42]. Womack, J. P.; Jones, D. T\& .Roos, D .(1991) .The Machine That Changed the World : The Story of Lean Production . Harper Perennial.

[43].Supply Chain Management and lean manufacturing .www.prozheha.ir

[44]. Site Club of Industrial Engineers.Iran .www.ieclub.ir 